\title{
Mapping actual distribution of invasive species siam weed and its abundance across biogeographical zones in Benin (West Africa)
}

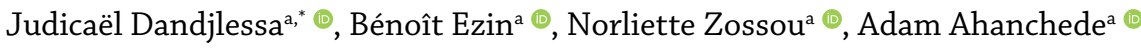 \\ ${ }^{a}$ Faculty of Agricultural Sciences, University of Abomey-Calavi, Abomey-Calavi, Atlantic, Benin.
}

Abstract: Background: Invasive weeds pose a serious threat to agricultural systems worldwide and the management of such species requires information on their distribution.

Objective: This research work aimed at assessing the evolution in the distribution of Siaw weed across biogeographical zones in Benin as first step toward the development of management policy and to give insight into the threat it poses to agriculture and biodiversity.

Methods: Field and roadside surveys were carried out to record the presence of the species. Geographical coordinates were collected and incorporated in GIS software to map the distribution of the plant. Abundance data were submitted to analysis of variance to compare infestation level across biogeographical zones, and correlation of the species distribution with environmental factors was examined.
Results: The extent of occurrence of the species has increased and fell within latitudes $6^{\circ} 30^{\prime}$ and just beyond $10^{\circ}$ North and range from about $0 \mathrm{~m}$ to $438 \mathrm{~m}$ in elevation, covering the entire area from south to center, and in part the north of the country. This weed is significantly more abundant in sudano-guinean zone $(7.28 \pm 0.18)$ than guinean zone $(4.72 \pm 0.20)$ and sudanian zone $(3.5 \pm 0.5)$. The species distribution is significantly correlated to the major climate variables and soil $\mathrm{pH}$.

Conclusion: The distribution of Siam weed mapped here shows progress in its occurrence points. Further studies are needed to better investigate the importance of soil and climate variables in its distribution and the vulnerability of the center zone ecosystems.

Keywords: Chromolaena odorata, alien invasive species, biological invasion, geographical range, Benin.

Journal Information:

ISSN - 2675-9462

Website: http://awsjournal.org

Journal of the Brazilian Weed

Science Society

How to cite: Dandjlessa J, Ezin B Zossou N, Ahanchede A. Mapping actual distribution of invasive species siam weed and its abundance across biogeographical zones in Benin (West Africa). Adv Weed Sci. Adv Weed Sci. 2021; e20210081.

https://doi.org/10.51694/AduWeedSci/2021;39:00022

Approved by:

Editor in Chief: Carlos Eduardo Schaedler

Associate Editor: José Barbosa Santos

Conflict of Interest: The authors declare that there is no conflict of interest regarding the publication of this manuscript.

Received: August 25, 2021

Approved: November 29, 2021

* Corresponding author: <dandjlessa94@yahoo.com>

\section{(c) (1)}

This is an open-access article distributed under the terms of the

Creative Commons Attribution License, which permits unrestricted use, distribution, and reproduction in any medium, provided that the original author and source are credited.

Copyright: 2021

\section{Introduction}

The development of international trade and the increased exchange of foods around the world have contributed to the dispersal of many plant species outside their native areas (Hulme, 2009). Biological invasions have turned out to be a real problem that weed scientists have been trying to address for decades without much success (Patoka et al., 2018). Many thousands of plant species around the world have been fortuitously introduced into environments other than their native areas by humans, animals and other (Kleunen et al., 2015). Many of them have established themselves in these new environments, taking advantage of more or less favorable ecological conditions and/or using their bioecological potential for adaptation and causing ecological and economic damages (Russell, Blackburn, 2017). These species are referred to as invasive alien species based on the above mentioned considerations (International Union for Conservation of Nature, 2000).

Invasive alien species are characterized by potentials that contribute to their establishment in the habitats they invade to the detriment of native plants that they smother through competition for environmental resources and other means (Estrada, Flory, 2015). Most of the invasive alien plant species in this category are weeds that are present in all kinds of ecosystems, both terrestrial and aquatic, where they pose problems of various kinds (Weidlich et al., 2020).

Siam weed, Chromolaena odorata (L.) King and Robinson (Asteraceae: Eupatorieae) (formerly known as Eupatorium odoratum L.), is one of the invasive exotic plant species, and weed native to South America, and widespread throughout tropical and subtropical environments worldwide (Raimundo et al., 2007). It is ranked among the 100 most invasive species (both plant and animal) in the world (Lowe et al., 2000) and is one of the major causes of biodiversity losses along with other invasive alien species of its rank (Tiébré, Gnanazan, 2018).

C. odorata was accidentally introduced in West Africa, notably in south-eastern Nigeria, via Asia in the 1930s (Ivens, 1974). It was reported in Benin several decades ago where it is considered probably introduced into the southeast of the country from Nigeria in the 1970s (Yehouenou, 1993). It became established throughout southern Benin and later invaded the Sudano-Guinean transitional climatic zone between the North and the South (Yehouenou, 1993; Aboh et al., 2008). 
Distribution of C. odorata was first assessed through field survey work by Yehouenou (1993), and later Fandohan et al. (2015) also gathered documentary sources that reported its occurrence in various regions of the country to predict its potential distribution regarding current and future climate. Siam weed continues to spread across phytogeographic zones of the country, as new points of occurrence are often reported. It is now present in agricultural systems as well as in grasslands, pastures, natural vegetation, urban environments, and protected areas, where it poses a threat to agriculture, livestock, and biodiversity (Aboh et al., 2008).

Although a potential distribution research work of $C$. odorata carried out by Fandohan et al. (2015) predicted a decrease in the suitable areas to its infestation at national level, its extent of occurrence in Benin has changed compared to recent decades during which it was found between $6^{\circ}$ and $9^{\circ} \mathrm{N}$ latitude. It is then compulsory to delimit its geographic range to monitor the dynamics of the invasion and to avoid its outbreak in other areas not yet invaded.

This research work aimed at mapping the actual extent of occurrence of $C$. odorata across phytogeographical areas in Benin to give insight of the importance of the invasion and the threat it represents to agricultural system and biodiversity.

\section{Material and methods}

\subsection{Study area}

The country of focus of this study is the republic of Benin. Benin is a West-African country ranging from latitude $6^{\circ} 30^{\prime}$ to $12^{\circ} 30^{\prime}$ North and longitude $1^{\circ}$ to $3^{\circ} 40^{\prime}$ East. The country covers $112,622 \mathrm{~km}^{2}$ and is subdivided into three main climatic regions such as the sub-humid humid, sub-humid dry and the semi-arid regions. Location and characteristic of each of these three climatic zones are summarized in Table 1.

\begin{tabular}{l|c|c|c|}
\hline \multicolumn{3}{|l}{ Table 1 - Characteristics of the three climatic regions of the } \\
study area
\end{tabular}

Source: Gnanglè et al. (2011)
The entire area of study is divided into three Phytochorological (biogeographical) zones: GuineoCongolian region, Guineo-Sudanian region (transition zone), and Sudanian region; and subdivided in 10 phytogeographical districts: Coast, Pobe, Oueme Valley, Plateau, Zou, Bassila, South Borgou, North Borgou, Mekrou-Pendjari and Atacora chain (Figure 1).

\subsection{Data collection}

Field and roadside surveys were carried out in the 10 phytodistricts of Benin from march to April and august to September 2020 to collect information on the presence/ absence of Chromolaena odorata. Transects were defined within each phytodistrict. Along transects at each $10 \mathrm{~km}$, the presence of the species was checked and the occurrence points, their geographical coordinates (longitude and latitude) and altitudes were recorded using GPS receiver device GARMIN 60s. A voucher specimen of the plant species was botanically authenticated by Professor Aristide ADOMOU of the National Herbarium of Benin, and deposited at Laboratory of Plant Biology, Faculty of Agricultural Sciences, University of Abomey-Calavi.

The type of vegetation with the species at each zone was also marked and the abundance of the species was assessed by absolute cover widely used in weed science to express it as percent of the land area covered by a particular weed species, when viewed from above. Common categories used are: $0-1 \%, 1-5 \%, 5-10 \%, 10-15 \%, 15-25 \%, 25-50 \%$, $50-75 \%$, and $75-100 \%$. In order to perform analysis, the cover-abundance values were later transformed in numerical scale as 2: 0-1\%, 3: 1-5\%, 4: 5-10\%, 5: 10-15\%, 6: $15-25 \%, 7: 25-50 \%, 8: 50-75 \%, 9: 75-100 \%$ according to the Maarel (1979).

Environmental data consisted in climate variables (humidity in \%, rainfall in $\mathrm{mm}$, rainfall regime and temperature in ${ }^{\circ} \mathrm{C}$ ) and soil $\mathrm{pH}$ were obtained from Meteorological Agency of Benin and previously published data (Igue et al., 2013; Hounkpatin et al., 2021), respectively.

\subsection{Data analysis}

Geographical coordinates were used to map distribution of Chromolaena odorata in Benin using Geographical Information System (GIS) software ArcGIS version 10.5. Abundance was expressed as mean \pm standard error of mean $(\mathrm{m} \pm \mathrm{SE})$ in order to compare the invasion level of different ecosystems surveyed in each climatic region.

Analysis of variance and Student-Newman-Keuls test were performed on abundance data to compare the infestation level across climatic zones. As environmental data were not normally distributed, Spearman rank correlation test was used to statistically correlate the species distribution to environmental factors. All the analysis was performed at $95 \%$ confidence interval using statistical software R version 4.0.4. 

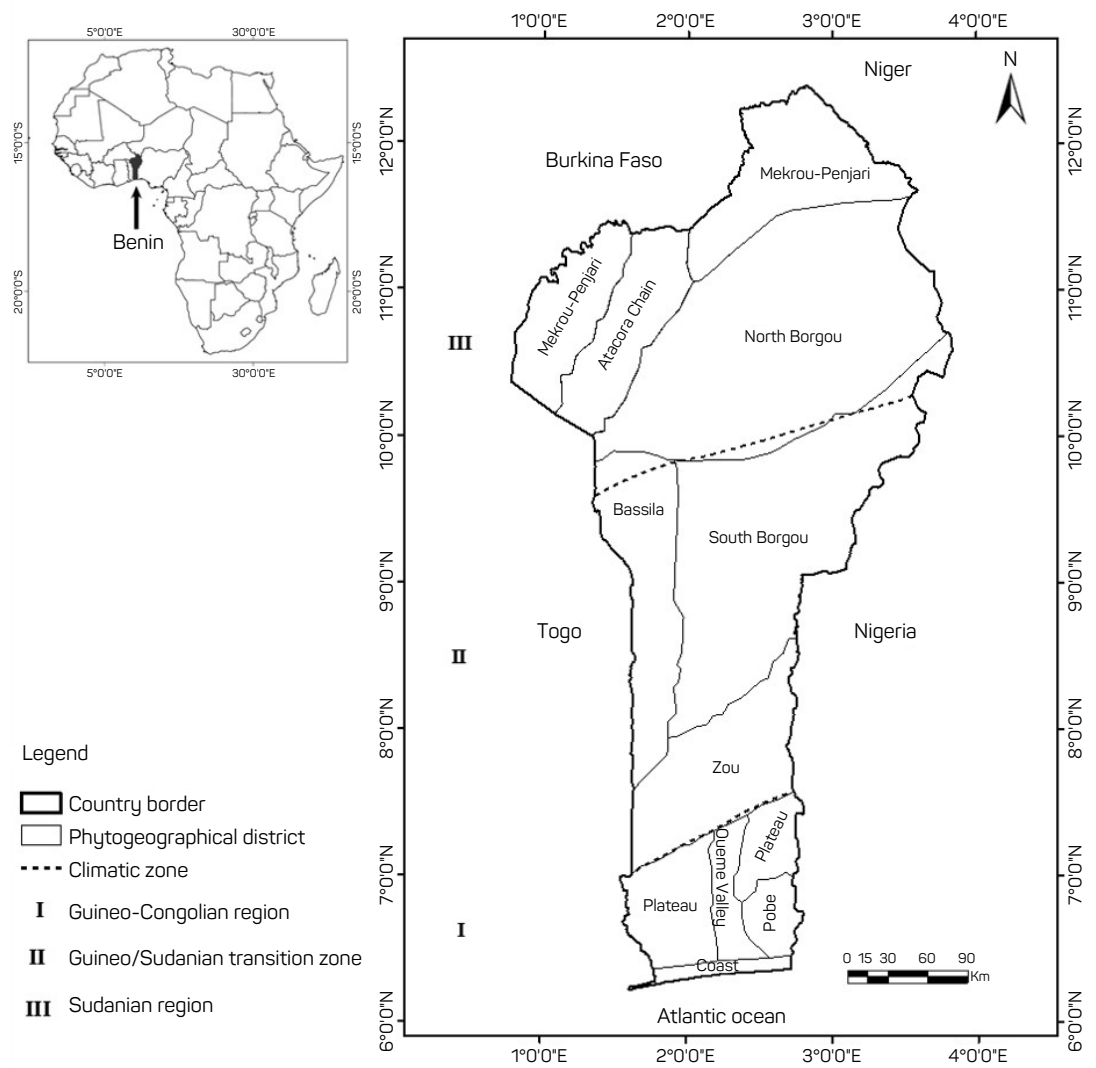

Figure 1 - Location of the study area

Abundance was also interpolated in the distribution area using the Empirical Bayesian Kriging (EBK) to give a graphical insight into the spatial trend of the infestation across phytogeographical districts. EBK is a mapping method to predict values in unsampled locations using measured values of sampled locations by automatically applying several different semivariogram models (Gribov, Krivoruchko, 2020).

\section{Results and discussion}

\subsection{Geographical range of Chromolaena odorata and key factors of distribution}

The distribution of Chromolaena odorata presented in Figure 2a shows the occurrence of the species in the three phytogeographical areas of Benin such as the sudanian zone, the sudano-guinean zone and the guinean one. Eight phytogeographical districts out of the ten were already infested by Siam weed. These results show an increasing in its geographical range compared to the results of Yehouenou (1993) who reported the occurrence zones only in guinean and sudano-guinean zones. However, it was noted that the sudanian zone located in the northern part of the country is almost free of the invasion apart from the beginning of infestation reported at its southwestern parts. The extent of occurrence of the species was within latitudes $6^{\circ} 30^{\prime}$ and just beyond $10^{\circ}$ North and ranged from about $0 \mathrm{~m}$ to 438 $m$ in elevation, showing that Siam weed is still expanding the range of invasion. This trend of enlarging its ranges is a global problem that has already been reported in many countries of the world. This may be justified not only by the bioecological adaptation of alien species but also by the absence or failure of biological invasions policies mainly in low income countries (Uyi et al., 2014).

The extent of occurrence recorded in this study went beyond the one reported in the previous studies on the species in Benin. Indeed, the potential distribution of $C$. odorata predicted by Fandohan et al. (2015) using maximal entropy (MaxEnt) approach should not only exceed the sudano-guinean zone under current climate conditions, but also decrease from north to south regarding future climate projections. Many reasons may explain the differences between the actual distribution and the recent predicted one. First of all, the scale of the study for the potential distribution modeling was over 2,000 $\mathrm{km}$ and the soil variables were not included in the model for forecasting. With such scale, the accuracy of the study might be poorer than that of small scale where the soil variables could also help to better predict the distribution (Yates et al., 2010). Nath et al. (2019) have found that including soil variables and human activity factors in species distribution model help to get the current distribution close to the predicted one. 


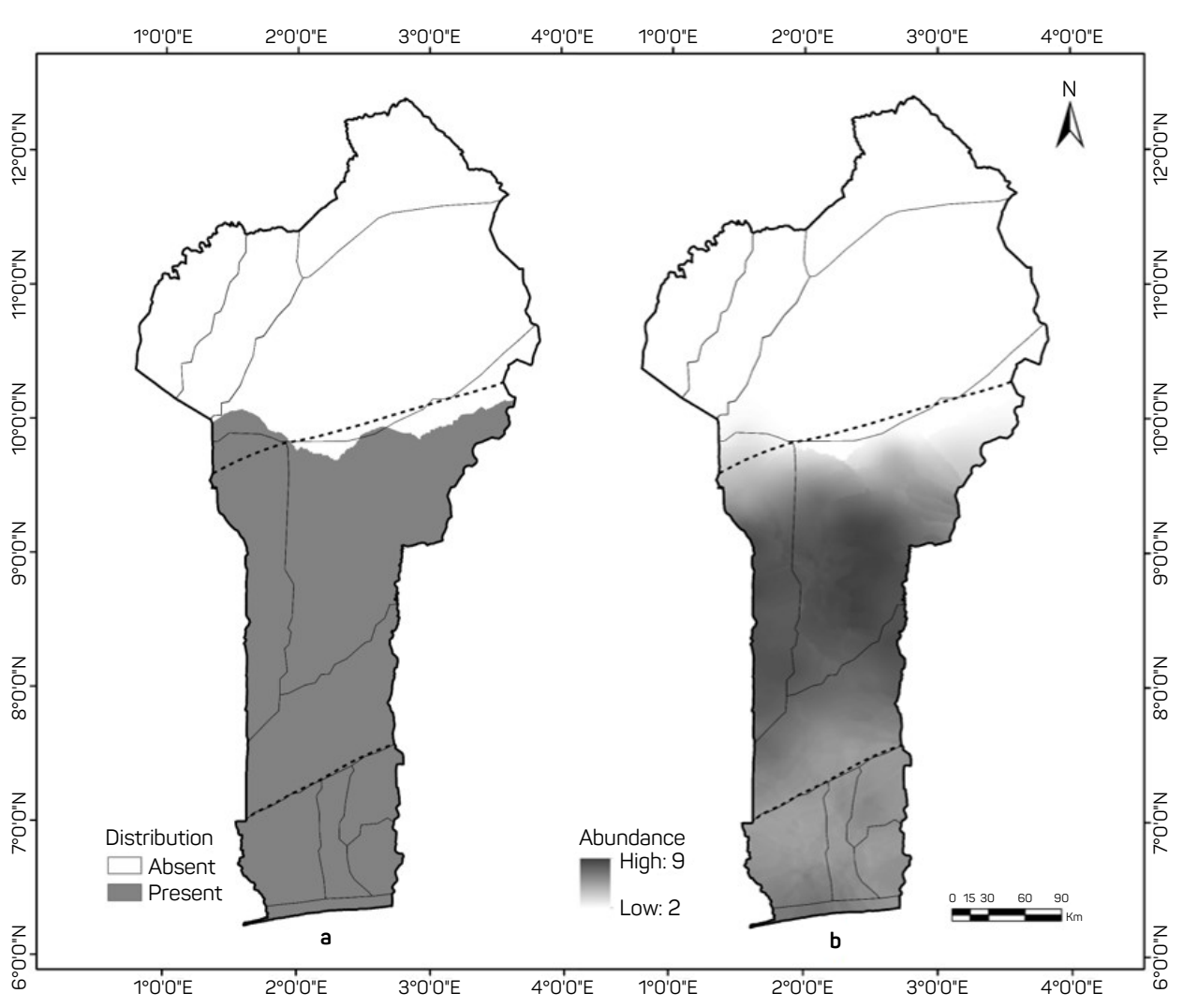

Figure 2 - Distribution (a) and abundance (b) of Siam weed

Although Siam weed is known to invade a large range of soil type, it was revealed a link between the occurrence of the species and the decline in the exchangeable potassium of the invaded soil indicating the importance of soil variables in biological invasions (Tiébré, Gnanazan, 2018). It is worth mentioning that a prediction is not an explanation and it could not help to understand the presence of a species at every occurrence point. Predictive models indeed do not include often others distribution factors apart from environmental variables (climate and sometimes soil) that are not enough to explain the introduction and the establishment of a given invasive species in an area. Furthermore, these kinds of models do not include the biological adaptation potential of plant species (evergreen, reproduction mode, size and number of seeds), the presence of pest associated with the species, and the human activities in the prediction of their potential distribution (Shmueli, 2010; Elith et al., 2011). These factors are more likely to explain and help to better predict the colonization by alien species (Szymura et al., 2018; Akin-Fajiye, Akomolafe, 2021).

The weed was not identified in the far north zone of the country and its absence in this zone could be as a result of the extreme weather and soil types in the zone which were not suitable to its development. The soils in the far north of the study zone are hydromorphic and this type of soil does not favor the invasion of $C$. odorata (Aboh et al., 2017). The minimum annual rainfall requirement for $C$. odorata is over $1,000 \mathrm{~mm}$ even though considerable lower limits have been recorded in some studies, and this may be a limiting factor to its occurrence in the far north as the annual rainfall over there is under 1,000 mm (Gnanglè et al., 2011). The same trend is observed in neighboring countries where the distribution of Siam weed is assessed. These findings are consistent with those of Uyi et al. (2014) reporting nonoccurrence of Siam weed in far north Nigeria, a neighboring country of Benin. They are also similar to the results of Aigbedion-Atalor et al. (2019) who reported its nonoccurrence in the north zone of Ghana.

\subsection{Abundance of $C$. odorata across its geographical range}

The distribution of $C$. odorata was not the same throughout its geographical range, and the interpolation results of its abundance show already differences in the overall infestation level (Figure $2 b$ ).

The species was more abundantly distributed in the sudano-guinean zone $(7.28 \pm 0.18)$ than in the guinean zone (4.72 \pm 0.24$)$ (Table 2). On the other hand, in the northern part (sudanian zone) of the country the lowest abundance of the species $(3.5 \pm 0.50)$ was recorded. Even though we lack detailed information, some factors could 
Table 2 - Abundance of Siam weed within different surveyed ecosystems

\begin{tabular}{|c|c|c|c|c|}
\hline Climatic zone & Agroecosystem & Protected area & Savannah & Total \\
\hline Guinean & $4.71 \pm 0.51$ & $4.28 \pm 0.52$ & $5.17 \pm 0.23$ & $4.72 \pm 0.24 b$ \\
\hline Guineo-Sudanian & $7.46 \pm 0.24$ & $7,50 \pm 0.76$ & $6.89 \pm 0.26$ & $7.28 \pm 0.18 a$ \\
\hline Sudanian & - & - & $3.50 \pm 0.50$ & $3.50 \pm 0.50 c$ \\
\hline Total & $6.08 \pm 0.30$ & $5.89 \pm 0.63$ & $5.18 \pm 0.19$ & \\
\hline
\end{tabular}

In the far right column, number with different letters are significantly different at $5 \%$ level

help partly explain the differences in the weed abundance across climatic zones of the country.

Soils in Center Benin are indeed classified as neutral to weakly acidic since their $\mathrm{pH}$ ranges from 6.6 to 7.2; while soils of southern Benin with $\mathrm{pH}$ from 4.9 to 6 are classified as very strongly to moderately acid (Igue et al., 2013). Siam weed grows best on soils with the potential hydrogen $(\mathrm{pH})$ value near to neutral (Aboh et al., 2017). This could be one of the raisons there was the highest level of infestation in the sudano-guinean zone compared to the guinean one. These results further corroborate with those of Aboh et al. (2017) who demonstrated that high infestations of $C$. odorata are only observed on soils with $\mathrm{pH}$ values around 7.12.

\subsection{Level of infestation in the invaded ecosystems}

The species has been recorded in almost all types of Benin terrestrial ecosystems: agricultural areas and fallows, forests and protected areas, pastures and grasslands, natural vegetation, waste grounds, rural and urban areas. The presence of the plant in almost all different types of ecosystems is an evidence of its status as an invasive plant that continues to invade new habitats in the West African region and also worldwide (Catarino et al., 2019).

In the guinean zone, savannahs are the most invaded ecosystems (5.17 \pm 0.23 ), followed respectively by agricultural areas $(4.71 \pm 0.51)$ and protected areas $(4.28$ $\pm 0.52)$; whereas in the transition zone, protected areas are the most affected ecosystems $(7.50 \pm 0.76)$. In the sudanian zone, on the other hand, the plant was only observed in natural vegetation (savannah) with a low abundance (3.50 \pm 0.50 ) during the surveys conducted in the framework of this work (Table 2). It is worth noting that agricultural ecosystems are the most infested overall $(6.08 \pm 0.30)$, followed by protected areas $(5.89 \pm 0.63)$, and savannahs come last (5.18 \pm 0.19$)$ (Table 2). These findings confirm that $C$. odorata is mainly an agricultural system weed, but also an alien invasive plant in forests and protected areas where it poses a real threat to biological diversity as reported in many studies (Fandohan et al., 2015; Tiébré, Gnanazan, 2018; Catarino et al., 2019).

Siam weed was recorded in fallow and major annual and perennial crops such as maize, cotton, cassava, sugarcane, orange, oil palm, shea nut and cashew nut. Observations made during the surveys showed that $C$. odorata is more abundant in fallow lands and perennial crops, especially

\begin{tabular}{l|c|c}
\hline \multicolumn{3}{|c}{ Table 3 - Correlation between species abundance and } \\
environmental variables
\end{tabular}

rho: Spearman correlation coefficient

cashew nuts, than in agricultural areas with annual crops. This is in accordance with the results of Aigbedion-Atalor (2020) who reported that $C$. odorata is perceived by farmers as a fallow weed although recognizing its enormous damage to crops; and those of Yehouenou (1993) who reported that the plant is very frequent and abundant in industrial crops.

\subsection{Relationship between species distribution and environmental factors}

The species distribution showed significant, either positive or negative, correlation to all the environmental factors considered (Table 3).

On the one hand, species abundance was positively correlated to annual rainfall ( $\mathrm{p}<0.028$ ), altitude and soil $\mathrm{pH}(\mathrm{p}<0.001)$. This implies that when one of these variables increase, the species abundance tends to increase too. On the other hand, a negative correlation was found between species abundance and relative rainfall regime, humidity and average annual temperature $(\mathrm{p}<0.001)$, supposing a tendency in the species abundance to decrease with an increasing value of one of these factors. However, it is worth mentioning that correlation is not causation but just measures how variables are linked to one another with regard to the direction and strength of the relationship.

These findings are consistent with previous studies on the species distribution ecology in Sub-Saharan African region and elsewhere. Indeed, while Fandohan et al. (2015) reported high contribution of rainfall to the species occurrence in West Africa, Aboh et al. (2017) reported that the higher the soil $\mathrm{pH}$, the higher $\mathrm{C}$. odorata abundance, and Nath et al. (2019) reported C. odorata gradually distributed along altitude in Terai grasslands in India. 


\section{Conclusion}

Alien invasive species represent a threat to agriculture and biodiversity worldwide and their control requires information on their distribution. This study aiming at assessing geographical range of Chromolaena odorata in Benin phytogeographical zones has showed that its current distribution is larger than few years ago when it was limited to guinean and sudano-guinean climatic zones.

The far north zone was poorly invaded by Siam weed compared to the south and center zones with the highest abundance. The species distribution was significantly correlated to the major environmental factors of key importance in plant ecology. These results could help in the development of management policies of invasive species in agricultural ecosystems and protected areas.

It is necessary to model the potential distribution of $C$. odorata under current and future climate scenarios including soil variables to better predict the trend of its spread. This is of paramount importance in order to monitor the invasion and prevent the expansion of the species' geographic range.

\section{Author's contributions}

JD, NZ, and AA: conceptualization of the manuscript and development of the methodology. JD and BE: data collection and curation. JD, BE, and NZ: data analysis. JD, $\mathrm{BE}, \mathrm{NZ}$, and AA: data interpretation. AA: supervision. JD, $B E$, and NZ: writing the original draft of the manuscript. $\mathrm{NZ}$ and AA: writing, review and editing. All authors read and agreed to the published version of the manuscript.

\section{Acknowledgements}

Authors are grateful to Dr Marcel DONOU for providing valuable advice on the survey methodology and distribution mapping, Mr. Socrate Mahugnon AGONVINON for his contribution to the realization of the maps, and Dr Vincent EZIN for editing.

\section{Funding}

This research did not receive any external funding.

\section{References}

Aboh B, Houinato $M$, Oumorou $M$, Sinsin B. [Invasiveness of two exotic species, Chromoloeno odorato (Asteraceae) and Hyptis suoveolens (Lamiaceae), in relation with land use around Bétécoucou (Bénin)]. Belg J Bot. 2008;141(2):125-40. French. Available from: https://doi.org/10.2307/20794660

Aboh BA, Teka O, Djikpo R, Oumorou M, Mensah GA, Sinsin B. Topographic and edaphic factors determining Chromoloeno odoroto and Hyptis suaveolens invasion of grassland in the Guineo-Congolian/ Sudanian transition zone (Benin). J Appl Biosci. 2017;111(1):10916-24. Available from: https://doi.org/10.4314/jab.v111i1.8

Aigbedion-Atalor PO, Day MD, Idemudia I, Wilson DD, Paterson ID. With or without you: stem-galling of a tephritid fly reduces the vegetative and reproductive performance of the invasive plant Chromoloeno odorato (Asteraceae) both alone and in combination with another agent. BioContr. 2019;64(1):103-14. Available from: https://doi. org/10.1007/s10526-018-09917-x

Aigbedion-Atalor PO. Weed or not a weed? Density, perceptions and management of Chromoloeno odorato (Asteraceae) in West Africa: voices from Ghana. Weed Res. 2020;60(6):406-14. Available from: https://doi.org/10.1111/wre.12439

Akin-Fajiye M, Akomolafe G. Disturbance is an important predictor of the distribution of Lantono camaro and Chromoloeno odorato in Africa. Vegetos. 2021;34(1):42-9. Available from: https://doi. org/10.1007/s42535-020-00179-6

Catarino L, Indjai B, Duarte MC, Monteiro F. Chromolaena odorata invasion in Guinea-Bissau (West Africa): first records and trends of expansion. Biolnvas Rec. 2019;8(1):190-8. Available from: https://doi.org/10.3391/bir.2019.8.1.20

Elith J, Phillips SJ, Hastie T, Dudík M, Chee YE, Yates CJ. A statistical explanation of MaxEnt for ecologists. Divers Distrib. 2011;17(1):43-57. Available from: https://doi.org/10.1111/j.1472-4642.2010.00725.x
Estrada JA, Flory SL. Cogongrass (Imperato cylindrica) invasions in the US: mechanisms, impacts, and threats to biodiversity. Global Ecol Conserv. 2015;3:1-10. Available from: https://doi.org/10.1016/j.gecco.2014.10.014

Fandohan $A B$, Oduor $A M$, Sodé $A l, W u ~ L$, Cuni-Sanchez $A$, Assédé $E$ et al. Modeling vulnerability of protected areas to invasion by Chromoloeno odorato under current and future climates. Ecosyst Health Sust. 2015;1(6):1-12. Available from: https://doi.org/10.1890/ EHS15-0003.1

Gnanglè CP, Kakaï RG, Assogbadjo AE, Vodounnon S, Yabi JA, Sokpon N. [Past climate trends: modeling, local perceptions and adaptation in Benin]. Climatologie. 2011;8:27-40. French. Available from: https://doi.org/10.4267/climatologie.259

Gribov A, Krivoruchko K. Empirical bayesian kriging implementation and usage. Sci Total Environ. 2020;722. Available from: https://doi.org/10.1016/j.scitotenv.2020.137290

Hounkpatin KOL, Bossa AY, Yira Y, Igue MA, Sinsin BA. Assessment of the soil fertility status in Benin (West Africa): digital soil mapping using machine learning. Geod Reg. 2021;28:1-14. Available from: https://doi.org/10.1016/j.geodrs.2021.e00444

Hulme PE. Trade, transport and trouble: managing invasive species pathways in an era of globalization. J Appl Ecol. 2009;46(1):10-8. Available from: https://doi.org/10.1111/j.1365-2664.2008.01600.x

Igue A, Saidou A, Adjanohoun A, Ezui G, Attiogbe P, Kpagbin G et al. [Soil fertility evaluation in south and central Benin]. Bull Rech Agron Bénin. 2013(spe):12-23. French.

International Union for Conservation of Nature - IUCN. IUCN guidelines for the prevention of biodiversity loss caused by alien invasive species. Gland: International Union for Conservation of Nature; 2000. 
Ivens GW. The problem of Eupatorium odoratum L. in Nigeria. Pest Artic News Summ. 1974;20(1):76-82. Available from: https://doi.org/10.1080/09670877409412338

Kleunen M, Dawson W, Essl F, Pergl J, Winter M, Weber $E$ et al. Global exchange and accumulation of non-native plants. Nature. 2015;525(7567):100-3. Available from: https://doi.org/10.1038/ nature14910

Lowe S, Browne M, Boudjelas S, Poorter M. 100 of the world's worst invasive alien species: a selection from the global invasive species database. Auckland: Invasive Species Specialist Group; 2000.

Maarel E. Transformation of cover-abundance values in phytosociology and its effects on community similarity. Vegetatio. 1979;39(2):97-114. Available from: https://doi.org/10.1007/BF00052021

Nath A, Sinha A, Lahkar BP, Brahma N. In search of aliens: factors influencing the distribution of Chromoloeno odorato $\mathrm{L}$. and Mikonia microntho Kunth in the Terai grasslands of Manas National Park, India. Ecol Engin. 2019;131:16-26. Available from: https://doi.org/10.1016/j.ecoleng.2019.02.012

Patoka J, Magalhães ALB, Kouba A, Faulkes Z, Jerikho R, Vitule JRS. Invasive aquatic pets: failed policies increase risks of harmful invasions. Biodivers Conserv. 2018;27(11):3037-46. Available from: https://doi.org/10.1007/s10531-018-1581-3

Raimundo RLG, Fonseca RL, Schachetti-Pereira R, Peterson AT, Lewinsohn TM. Native and exotic distributions of siamweed (Chromoloeno odorato) modeled using the genetic algorithm for rule-set production. Weed Sci. 2007;55(1):41-8. Available from: https://doi.org/10.1614/WS-06-083.1.

Rodenburg J, Morawetz JJ, Bastiaans L. Rhomphicarpo fistuloso, a widespread facultative hemi-parasitic weed, threatening rice production in Africa. Weed Res. 2015;55(2):118-31. Available from: https://doi.org/10.1111/wre.12129
Russell JC, Blackburn TM. Invasive alien species: denialism, disagreement, definitions, and dialogue. Trends Ecol Evol. 2017;32(5):312-4. Available from: https://doi.org/10.1016/j.tree.2017.02.005

Shmueli G. To explain or to predict? Stat Sci. 2010;25(3):289-310. Available from: https://doi.org/10.1214/10-STS330

Szymura TH, Szymura M, Zając M, Zając A. Effect of anthropogenic factors, landscape structure, land relief, soil and climate on risk of alien plant invasion at regional scale. Sci Total Environ. 2018;626:1373-81. Available from: https://doi.org/10.1016/j.scitotenv.2018.01.131

Tiébré MS, Gnanazan ZRG. Impact of Chromolaeno odorato (L.) RM King \& H. Rob.(Asteraceae) on the floristic composition and the physico-chemical properties of the soil of a coastal relict forest. Int J Innov Appl Study. 2018;24(2):773-88.

Uyi OO, Ekhator F, Ikuenobe CE, Borokini TI, Aigbokhan El, Egbon IN et al. Chromoloeno odoroto invasion in Nigeria: a case for coordinated biological control. Manag Biol Invasions. 2014;5(4):377-93. Available from: https://doi.org/10.3391/mbi.2014.5.4.09

Weidlich EW, Flórido FG, Sorrini TB, Brancalion PH. Controlling invasive plant species in ecological restoration: a global review. J Appl Ecol. 2020;57(9):1806-17. Available from: https://doi.org/10.1111/13652664.13656

Yates CJ, Elith J, Latimer AM, Maitre D, Midgley GF, Schurr FM et al. Projecting climate change impacts on species distributions in megadiverse South African Cape and Southwest Australian Floristic Regions: opportunities and challenges. Austral Ecol. 2010;35(4):374-91. Available from: https://doi.org/10.1111/j.1442-9993.2009.02044.x

Yehouenou A, editor. [A survey of Chromoloeno odorato in Benin]. In: Proceeding of 3th International Workshop on biological control and management of Chromoloeno odorato; Abidjan, Côte d'Ivoire. Mangilao: University of Guam; 1996. p. 19-22. French. 